\title{
SISTEM INFORMASI AKADEMIK STKIP HAMZANWADI SELONG MENGGUNAKAN TECHNOLOGY ACCEPTANCE MODEL
}

\author{
${ }^{1}$ Jamaludin, ${ }^{2}$ Muhammad Khairul Rizal \\ ${ }^{1}$ Program Studi Pendidikan Informatika, Fakultas Keguruan dan Ilmu Pendidikan, \\ Universitas Hamzanwadi \\ ${ }^{2}$ Program Studi Sistem Informasi, Fakultas Teknik, Universitas Hamzanwadi \\ E-mail: jamal.ict@hamzanwadi.ac.id ${ }^{1}$, mkrizal@gmail.com ${ }^{2}$
}

\begin{abstract}
Abstrak
Sistem Informasi Akademik (SIAKAD) adalah salah satu bagian yang menjadi sangat penting bagi perguruan tinggi saat ini. Hal ini dapat mempermudah akses seorang mahasiswa dalam berinteraksi dengan kampusnya. Selain itu SIAKAD juga akan meningkatkan daya saing perguruan tinggi tersebut dan secara langsung akan meningkatkan proses bisnis lembaga. Untuk mengoptimalkan sistem informasi akademik, maka harus dilakukan penelitian dengan cara mengevaluasi penggunaan sistem dari SIAKAD tersebut. Penelitian ini ditujukan untuk mengevaluasi penggunaan SIAKAD di STKIP Hamzanwadi selong dengan menggunakan metode Technology Acceptance Model (TAM), dan untuk mengolah data survei tersebut menggunakan software Partial Least Square untuk mengukur persepsi pengguna terhadap SIAKAD apakah berjalan sesuai fungsinya. Data yang diperoleh merupakan data primer dengan menggunakan kuesioner kepada mahasiswa pengguna SIAKAD yang terdiri dari beberapa jurusan. Variabel-variabel yang digunakan adalah Perceived Easy of Use, Perceived Usefulness, Attitude Towards Using Technology, Behavioral Intention to Use dan Actual Technology Use. Hasil penelitian ini menunjukkan bahwa SIAKAD SIAM memiliki manfaat dan mudah untuk digunakan oleh mahasiswa selaku pengguna, dan seluruh fitur teknologi pada aplikasi SIAKAD memiliki manfaat dengan diterimanya Variabel Actual Technology Use.
\end{abstract}

Kata Kunci: Sistem Informasi Akademik, TAM

\begin{abstract}
Academic Information System (SIAKAD) is one part that is very important for universities today. This can facilitate the access of a student in interacting with the campus. In addition, SIAKAD will also improve the competitiveness of these universities and will directly improve the institution's business processes. To optimize the academic information system, research must be conducted by evaluating the use of the system from the SIAKAD. This study is intended to evaluate the use of SIAKAD in STKIP Hamzanwadi Selong by using the Technology Acceptance Model (TAM) and to process the survey data using Partial Least Square software to measure user perceptions of SIAKAD whether it works according to its function. The data obtained is primary data using a questionnaire to students using SIAKAD which consists of several departments. The variables used are Perceived Ease of Use, Perceived Usefulness, Attitude towards Using Technology, Behavioral Intention to Use and Actual Technology Use. The results of this study indicate that SIAKAD SIAM has benefits and is easy to use by students as users, and all technology features in the SIAKAD application have benefits with the receipt of the Actual Technology Use Variable.
\end{abstract}

Keyword: Information System Academic, TAM

\section{PENDAHULUAN}

Peranan teknologi informasi dalam membantu proses bisnis perusahaan dewasa ini sudah menjadi suatu keharusan untuk diterapkan. Kecepatan mendapatkan data dan informasi yang dibutuhkan oleh perusahaan memberikan kontribusi yang banyak bagi perusahaan untuk membuat kebijakan atau terobosan yang menguntungkan. Dampaknya adalah perusahaan 
memiliki daya saing yang tinggi dan mampu melihat peluang yang lebih baik dimasa yang akan datang.

Perguruan Tinggi (PT) adalah salah satu contoh perusahaan dibidang pendidikan yang memiliki kompleksitas data dan memiliki pertukaran data antar departemen yang sangat sering, hal ini membutuhkan dukungan teknologi dalam proses bisnisnya. Teknologi yang terdiri dari Sistem Informasi (SI) yang berupa aplikasi yang berjalan dan Teknologi Informasi (TI) yang berupa infrastruktur seperti perangkat keras di dalamnya membutuhkan komitmen dan kebijakan khusus dari PT karena membutuhkan biaya yang besar serta tidak mudah untuk diterapkan terlebih lagi pada daerah-daerah yang masih memiliki dukungan infrastruktur teknologi cukup rendah seperti Indonesia bagian tengah dan timur.

Perguruan tinggi swasta yang cukup tua di Indonesia bagian timur ini adalah Sekolah Tinggi Keguruan dan Ilmu Pendidikan (STKIP) Hamzanwadi Selong yang telah berdiri sejak tahun 1972, terdiri dari 15 program studi dan telah memiliki beberapa system informasi sistem informasi akademik mahasiswa (SIAM), sistem informasi monitoring akademik (SIMA), sistem registrasi akademik (SIRAK), perpustakaan digital (Digital Library), Sistem Penerimaan Mahasiswa Baru (SPMB), sistem informasi keuangan (SIMKEU), Sistem Informasi Wisuda dan system lainnya yang belum pernah di lakukan evaluasi, sehingga belum dapat di ketahui sejauh mana system-sistem tersebut sudah berjalan dan memberikan kontribusi terhadap lembaga. Sistem informasi yang ada saat ini merupakan bagian dari prioritas STKIP Hamzanwadi Selong dalam 5 tahun ke depan yaitu untuk meningkatkan mutu layanan pendidikan dan pengajaran serta layanan sumber belajar berbasis TI, penataan kelembagaan dan sistem manajemen berbasis TI di setiap program studi dan unit bisnis lainnya (Renstra STKIP Hamzanwadi Selong, 2011-2015). Tujuan dari penelitian ini adalah: (1) Mengidentifikasi faktor-faktor penentu yang mempengaruhi pemanfaatan SIAKAD SIAM sebagai salah satu manajemen akademik berbasis teknologi informasi di STKIP Hamzanwadi Selong, (2) Mengetahui cara untuk mengatasi faktor-faktor yang mempengaruhi pemanfaatan SIAKAD SIAM sebagai salah satu manajemen akademik berbasis teknologi informasi di STKIP Hamzanwadi Selong.

\section{TINJAUAN PUSTAKA}

\section{Sistem Informasi}

Kadir (2003) menjabarkan sistem informasi merupakan cakupan dari sejumlah komponen (manusia, komputer, teknologi informasi dan prosedur kerja), ada sesuatu yang diproses (data menjadi informasi), dan dimaksudkan untuk mencapai suatu sasaran atau tujuan. Notohadiprawiro (2006), istilah sistem informasi menyiratkan suatu pengumpulan data yang terorganisasi beserta tatacara penggunaanya yang mencakup lebih jauh dari sekedar penyajian. Keberhasilan suatu sistem informasi seperti yang dikutip oleh Notohadiprawiro bergantung pada tiga faktor utama yaitu: (1) keserasian dan mutu data, (2) pengorganisasian data, dan (3) tatacara penggunaannya.

\section{Sistem Informasi Akademik (SIAKAD)}

Sistem Informasi Akademik (SIAKAD) STKIP Hamzanwadi Selong merupakan system yang secara manajemen terintegrasi antara satu unit dengan unit yang lainnya. System ini dapat di akses melalui alamat http://www.hamzanwadi.ac.id atau www.siakad.hamzanwadi.ac.id SIAKAD dikembangkan pertama kali tahun 2012 dengan modifikasi yang sudah dilakukan lebih dari empat kali modifikasi. Rekayasa ulang yang pernah dilakukan disebabkan karena perubahan kebijakan dari lembaga. Efisiensi, efektifitas dan persaingan untuk memberikan pelayanan yang baik kebapada seluruh civitas akademik merupakan salah satu alasan SIAKAD di kembangkan, hingga saat ini SIAKAD sudah 
memiliki 7 aplikasi diantaranya adalah, Sistem Penerimaan Mahasiswa Baru (SPMB), Sistem Informasi Keuangan (SIKU), Sistem Informasi Registrasi Akademik (SIRAK), Sistem Informasi Akademik Mahasiswa (SIAM), Sistem Informasi Monitoring Akademik (SIAM), Sistem Informasi Pelaporan (SIMPEL), Perpustakaan digital, Sistem Informasi wisuda (SIDA).

\section{Technology Acceptance Model (TAM)}

Technology Acceptance Model (TAM) merupakan salah satu model yang dibangun untuk menganalisis dan memahami faktor-faktor yang mempengaruhi diterimanya penggunaan teknologi komputer. Diperkenalkan pertama kali oleh Fred Davis pada tahun 1986. TAM merupakan hasil pengembangan dari Theory of Reasoned Action (TRA), yang lebih dahulu dikembangkan oleh Fishbein dan Ajzen pada 1980. TAM bertujuan untuk menjelaskan dan memperkirakan penerimaan (acceptance) pengguna terhadap suatu sistem informasi. TAM menyediakan suatu basis teoritis untuk mengetahui faktor-faktor yang mempengaruhi penerimaan terhadap suatu tekhnologi dalam suatu organisasi.

TAM menjelaskan hubungan sebab akibat antara keyakinan (akan manfaat suatu sistem informasi dan kemudahan penggunaannya) dan perilaku, tujuan/keperluan, dan penggunaan aktual dari pengguna/user suatu sistem informasi. Davis et al. (1989) mendefinisikan persepsi atas kemanfaatan (perceived usefulness) sebagai "suatu tingkatan dimana seseorang percaya bahwa menggunakan sistem tersebut dapat meningkatkan kinerjanya dalam bekerja".Sedangkan Marvine Hamner et al. (2008) menambahkan Persepsi atas manfaat untuk diri sendiri (Perceive Personal Utility), dimana lebih mengacu pada manfaat yang diperoleh untuk pribadi sedangkan Perceive Usefulness mengacu pada manfaat untuk organisasi. Persepsi atas kemudahan penggunaan (Perceived ease of use), secara kontras, mengacu pada "suatu tingkatan dimana seseorang percaya bahwa menggunakan sistem tersebut tak perlu bersusah payah. Ini mengikuti definisi dari "mudah" ("ease"): "freedom from difficulty or great effort" atau "tidak memiliki kesulitan atau atau upaya keras".

TAM mendeskripsikan dua faktor yang secara dominan mempengaruhi integrasi teknologi informasi. Faktor pertama adalah persepsi pengguna terhadap manfaat teknologi (usefulness). Sedangkan faktor kedua adalah persepsi pengguna terhadap kemudahan penggunaan teknologi (ease-of-use). Selanjutnya kemauan untuk memanfaatkan teknologi akan mempengaruhi penggunanan teknologi yang sesungguhnya. Secara grafis dapat digambarkan seperti Gambar 2.2.

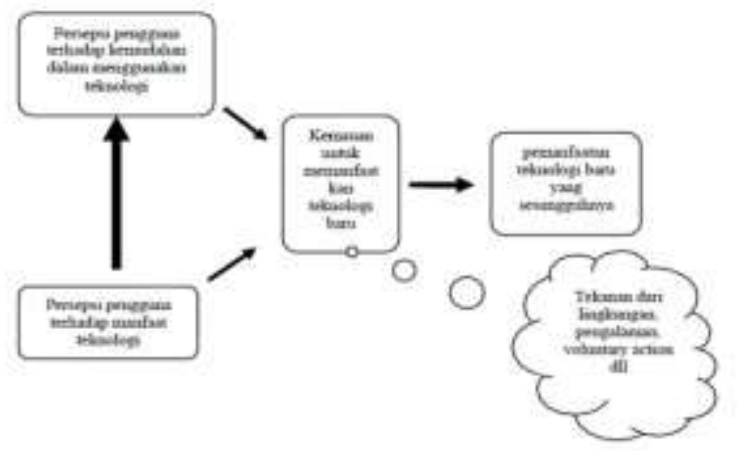

Gambar 1. Struktur Total Acceptance Model (TAM)

\section{Structural Equation Modeling (SEM)}

Structural Equation Modeling (SEM) adalah suatu teknik statistik yang memiliki kemampuan untuk menganalisis pola hubungan antara konstruk laten dan indikatornya, konstruk laten yang satu dengan lainnya serta kesalahan pengukuran secara langsung. SEM 
atau model persamaan struktural telah digunakan dalam berbagai bidang ilmu seperti psikologi, ekonomi, pendidikan dan ilmu sosial lainnya. SEM merupakan perkembangan dari beberapa keterbatasan analisis multivariat. Pedhazur di dalam Wijaya (2009) menyatakan SEM mengacu kepada hubungan antara variabel endogen (endogenous variables) dan variabel eksogen (exogenous variables), yang merupakan variabel tidak dapat diamati atau dihitung secara langsung (unobserved variables) atau variabel laten (latent variables).

Ada dua pendekatan dalam SEM, yaitu SEM dengan dasar covariance (CBSEM) dan SEM dengan pendekatan varians (VBSEM). Penggunaan SEM berbasis covariance dipermudah oleh software pengolah data seperti Lisrel, AMOS, dan EQS. Sedangkan SEM berbasis varians yang banyak digunakan adalah XLSTAT PLS-PM, PLS Graph, SmartPLS, Visual PLS dan lainnya. Penelitian ini menggunakan metode survei yang dilakukan dengan menyebarkan kuisioner kepada respoden. Pertanyaan pada kuisioner disajikan beserta pilihan jawaban. Responden diminta untuk memilih salah satu jawaban yang sesuai dengan responden dengan menggunakan skala Likert 1-5 [5 untuk Sangat Setuju (SS), nilai 4 untuk Setuju (S), nilai 3 Netral (N), nilai 2 untuk Tidak Setuju (TS) dan nilai 1 untuk Sangat Tidak Setuju (STS).

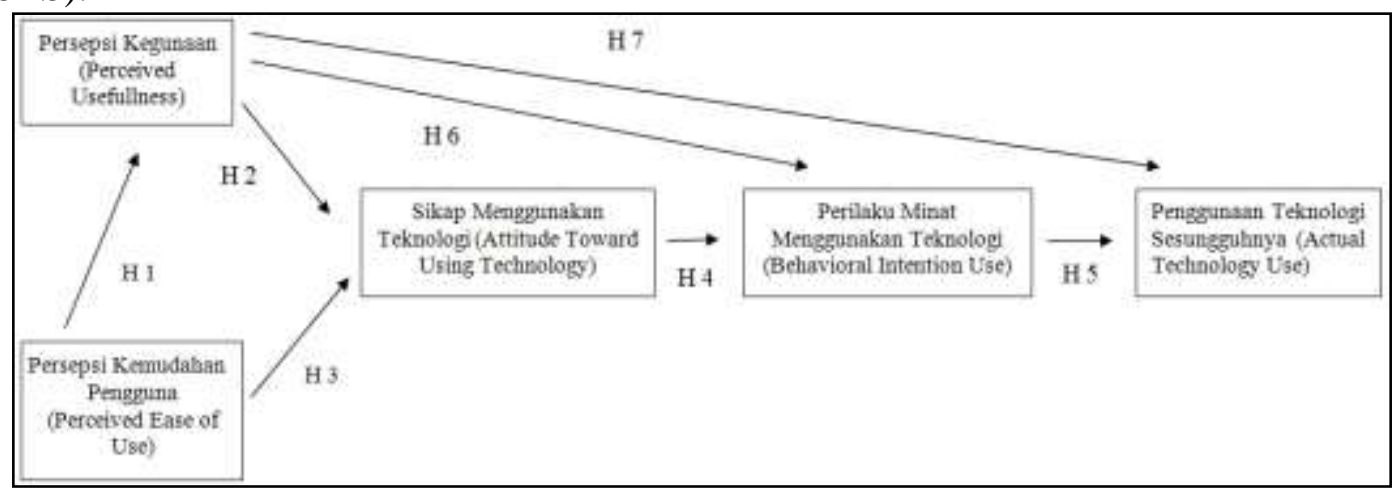

Gambar 2. Model Pengukuran TAM, Jogianto (2008)

\section{METODE}

Penelitian ini menggunakan integrasi Technology Acceptace Mode (TAM). Model penelitian ini dapat dilihat pada Gambar 2 dengan lima buah konstruk atau variabel sebagai acuan pengukuran SIAKAD yang akan digunakan. Populasi Populasi merupakan suatu wilayah generalisasi yang terdiri atas obyek/subyek, yang mempunyai karakteristik tertentu dan mempunyai kesempatan yang sama untuk dipilih menjadi anggota sampel. Secara umum suatu sampel yang baik adalah yang dapat mewakili sebanyak mungkin karakteristik populasi.

Analisis SEM mensyaratkan data berdistribusi normal untuk menghindari bias dalam analisis data. Data outlier harus dibuang karena menimbulkan bias dalam interpretasi dan menpengaruhi data lainnya. Data dikatakan normal apabila critical ratio (CR) memiliki syarat $-2,58<\mathrm{CR}<2,58$. Beberapa model yang digunakan dalam penelitian kuantitatif (Umar, 2003) seperti Slovin, Gay, Kracjie, Harry King. Dalam model Slovin, jumlah sampel dihitung dari suatu populasi dengan menghitung prosentase kelonggaran ketidaktelitian karena kesalahan pengambilan sampel yang masih dapat ditolerir atau diinginkan misalnya $2 \%$. Rumus yang digunakan dalam metode Slovin yaitu: $n=N /\left(1+\mathrm{Ne}^{2}\right)$ dimana $n$ adalah sampel, $\mathrm{N}$ adalah jumlah populasi dan e adalah prosentasi kelonggaran ketidaktelitian. Dalam metode Slovin memiliki asumsi bahwa populasi berdistribusi normal. Variabel pada penelitian ini adalah Variabel Dependent (terikat) yang terdiri dari: (1) PU = Percieved usefulness $=$ Persepsi kegunaan atau manfaat, (2) ATU = Attitude Toward Using = Sikap 
menggunakan teknologi, (3) BIU = Behavoiral Intention to Use = Perilaku minat menggunakan teknologi, (4) AU = Actual Use = Penggunaan sesungguhnya. Sementara itu Variable Independent (bebas) pada penelitian ini adalah PEOU = Percieved easy of use = Persepsi kemudahan pengguna. Instrument yang digunakan pada penelitian ini adalah kuesioner dengan menggunakan skala likert. Kisi-kisi instrumen pada penelitian ini dapat dilihat pada tabel berikut.

Tabel 1. Kisi-kisi Instrumen Penelitian

\begin{tabular}{|c|c|}
\hline \multicolumn{2}{|r|}{ Perceived Easy of Use (PEOU) atau persepsi kemudahan } \\
\hline PEOU_1 & Saya merasa mudah belajar mengoperasikan SIAKAD \\
\hline PEOU_2 & Saya merasa SIAKAD mudah untuk digunakan \\
\hline PEOU_3 & $\begin{array}{l}\text { Saya merasa sangat mudah untuk menjadi terampil dalam menggunakan } \\
\text { SIAKAD }\end{array}$ \\
\hline PEOU_4 & $\begin{array}{l}\text { Saya merasa mudah untuk mendapatkan informasi akademik saya dari } \\
\text { SIAKAD }\end{array}$ \\
\hline PEOU_5 & $\begin{array}{l}\text { Saya merasa mudah mendapatkan informasi tagihan pembayaran studi melalui } \\
\text { SIAKAD }\end{array}$ \\
\hline PEOU_6 & $\begin{array}{l}\text { SIAKAD dapat diakses di mana saja (misalnya : rumah, tempat kerja, } \\
\text { kampus). }\end{array}$ \\
\hline \multicolumn{2}{|r|}{ Perceived Usefulness (PU) atau persepsi kegunaan } \\
\hline PU_1 & Menggunakan SIAKAD dapat meningkatkan kinerja saya \\
\hline PU_2 & $\begin{array}{l}\text { Menggunakan SIAKAD dapat memudahkan saya dalam mengerjakan dan } \\
\text { menyelesaikan aktivitas perkulihan }\end{array}$ \\
\hline PU_3 & Menggunakan SIAKAD dapat meningkatkan efektivitas perkulihan \\
\hline PU_4 & Saya merasa SIAKAD bermanfaat bagi aktivitas perkulihan \\
\hline PU_5 & $\begin{array}{l}\text { Saya dapat meninjau kembali transaksi akademik saya di semester yang telah } \\
\text { lalu pada SIAKAD }\end{array}$ \\
\hline \multicolumn{2}{|r|}{ Attitude Towards Using Technology (AT) atau sikap menggunakan teknologi } \\
\hline AT_1 & Saya merasa nyaman dengan tampilan SIAKAD \\
\hline AT_2 & Saya senang berinteraksi dengan menggunakan SIAKAD \\
\hline AT_3 & Saya senang dengan fitur-fitur di SIAKAD \\
\hline AT_4 & Saya merasa terjamin keamanan account saya di SIAKAD \\
\hline & Saya senang dengan tampilan/interface SIAKAD \\
\hline BI_1 & Saya berniat menggunakan SIAKAD selama proses studi \\
\hline BI_2 & Saya berniat menggunakan SIAKAD sesering mungkin selama proses studi \\
\hline BI_3 & $\begin{array}{l}\text { Saya berniat memanfaatkan waktu luang saya di kampus untuk berinteraksi } \\
\text { dengan SIAKAD }\end{array}$ \\
\hline BI_4 & $\begin{array}{l}\text { Saya berniat mengikuti diskusi secara online melalui chatbox SIAKAD sesering } \\
\text { mungkin }\end{array}$ \\
\hline BI_5 & $\begin{array}{l}\text { Saya berniat menyarankan teman saya untuk menggunakan SIAKAD } \\
\text { Actual Technology Use (AU) atau penggunaan sesungguhnya }\end{array}$ \\
\hline AU_1 & Saya hanya menggunakan SIAKAD selama saya memerlukannya \\
\hline AU_2 & Saya mengakses SIAKAD hampir setiap minggu \\
\hline AU_3 & Ketika menggunakan SIAKAD saya mengaksesnya lebih dari 15 menit \\
\hline AU_4 & $\begin{array}{l}\text { Setiap kali ke kampus, saya selalu menyempatkan diri untuk mengakses } \\
\text { SIAKAD }\end{array}$ \\
\hline AU_5 & Saya merasa puas dengan kinerja SIAKAD \\
\hline
\end{tabular}

\section{HASIL DAN PEMBAHASAN}

Deskripsi responden pada penelitian ini berdasarkan jenis kelamin yang terdiri dari dua kategori yaitu pria dan wanita dengan rincian pria berjumlah 60 orang dan wanita sebanyak 160 orang. Gambar 3 merupakan grafik dari rincian responden. 


\section{Jumlah}

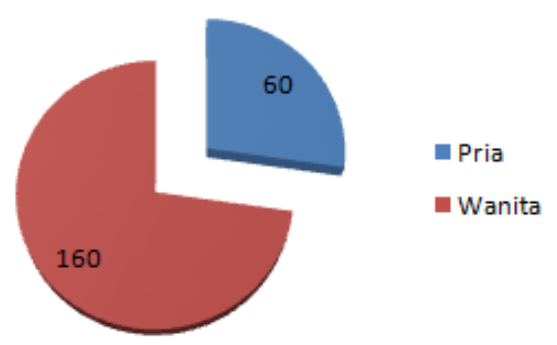

Gambar 3. Rincian Responden berdasarkan jenis Kelamin

Diagram jalur model penelitian dikembangkan berdasarkan hipotesis yang diajukan dalam penelitian ini. Berdasarkan Gambar 4 terlihat bahwa diagram jalur model penelitian bersifat reflektif.

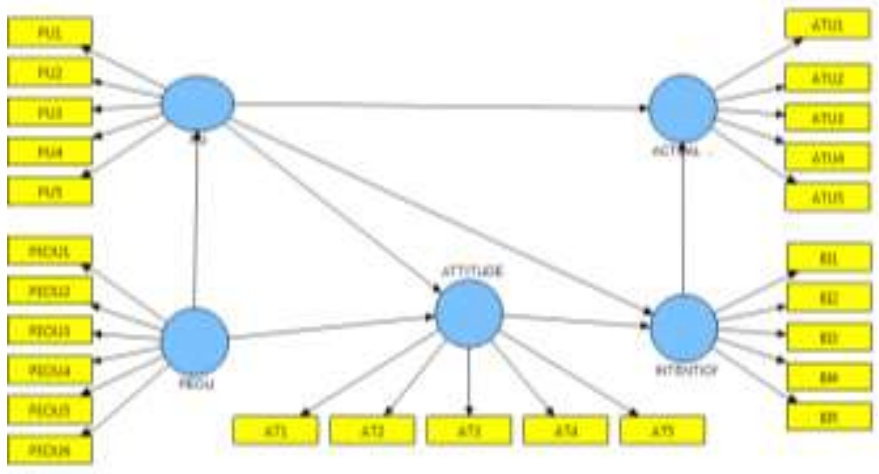

Gambar 4. Diagram jalur penelitian

\section{Evaluasi Model}

Convergent validity digunakan untuk mengetahui korelasi konstruk yang satu dengan konstruk lainnya. Evaluasi ini meliputi indikator validitas, reliabilitas konstruk dan nilai average variance extracted (AVE). Indikator validitas dinilai berdasarkan nilai standardized loading factor yang menggambarkan korelasi antar blok indikator dengan konstruk (variabel latennya). Nilai loading factor dikatakan baik apabila nilainya 0,7 Ghozali (2011), namun menurut Chin dalam Ghozali (2011) bahwa nilai loading factor 0,50 - 0,60 masih dapat diterima. Gambar 4.3 memperlihatkan model setelah dirunning

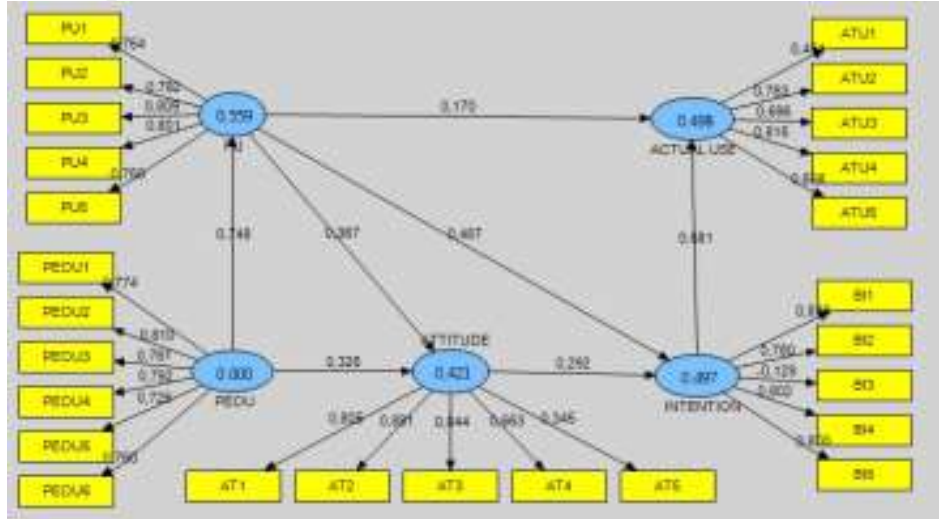

Gambar 5. Hasil running model PLS tahap awal 
Berdasarkan Gambar 5. terlihat bahwa konstruk attitude melalui indikator AT5, konstruk actual use melalui indikator ATU1, dan konstruk behavior intention melalui indikator BI3, memiliki loading faktor dibawah 0,60 sehingga indikator-indikator tersebut perlu dikeluarkan atau di drop dari model.

\section{Discriminant Validity}

Setelah dilakukannya disdriminat validity, nilai cross loading dianggap memenuhi syarat kriteria yang sudah ditetapkan. Selanjutnya dilakukan evaluasi terakhir dari discriminant validity adalah membandingkan antara akar AVE dengan korelasi antar konstruk. Kriterianya adalah bahwa akar AVE harus bernilai lebih besar jika dibandingkan dengan korelasinya dengan konstruk lainnya. Tabel 2 memperlihatkan nilai AVE dan akar AVE serta korelasi antar konstruk.

Tabel 2. Latent variable correlation dan akar AVE

\begin{tabular}{cccccc}
\hline & $\begin{array}{l}\text { Actual } \\
\text { Use }\end{array}$ & Attitude & Intention & PEOU & PU \\
\hline Actual Use & $0,69^{*}$ & & & & \\
Attitude & 0,61 & $0,73^{*}$ & & & \\
Intention & 0,68 & 0,58 & $0,72^{*}$ & & \\
PEOU & 0,59 & 0,61 & 0,66 & $0,76^{*}$ & \\
PU & 0,56 & 0,62 & 0,67 & 0,75 & $0,78^{*}$ \\
\hline
\end{tabular}

Berdasarkan Tabel 4.7 terlihat bahwa nilai akar AVE konstruk actual use lebih besar jika dibandingkan korelasinya dengan konstruk lainnya, dimana korelasi tertinggi adalah konstruk intention sebesar 0,78. Nilai akar AVE konstruk attitude adalah 0,84 lebih besar jika dibandingkan korelasinya dengan konstruk lainnya, dimana korelasi tertinggi adalah 0,77 dengan konstruk intention. Demikian seterusnya dengan konstruk lainnya. Selanjutnya dilakukan Evaluasi terhadap model struktural atau inner model dilakukan untuk mengetahui hubungan antar konstruk laten. Evaluasi ini terdiri dari dua tahap, yaitu hubungan signifkansi jalur untuk pengujian hipotesis dan nilai R-square guna penilaian terhadap goodnes of fit model. Hubungan signifikasi jalur dapat dilihat pada Tabel 4.8.

Tabel 3. Path coefficient

\begin{tabular}{lccl}
\hline & $\begin{array}{l}\text { Original } \\
\text { Sample } \\
(\mathbf{O})\end{array}$ & $\begin{array}{l}\text { T Statistics } \\
(\mid \text { O/STERR })\end{array}$ & Keterangan \\
\hline $\begin{array}{l}\text { Attitude -> intention } \\
\text { Intention -> Actual }\end{array}$ & 0,27 & 2,78 & $\begin{array}{l}\text { Sangat signifikan pada alpha 1\% dan 5\% } \\
\text { Sangat signifikan pada alpha 1\% dan 5\% }\end{array}$ \\
USE & 0,56 & 10,68 & \\
PEOU -> ATTITUDE & 0,33 & 3,83 & Sangat signifikan pada alpha 1\% dan 5\% \\
PEOU -> PU & 0,75 & 18,32 & Sangat signifikan pada alpha 1\% dan 5\% \\
PU -> ACTUAL USE & 0,18 & 2,57 & Sangat signifikan pada alpha 1\% dan 5\% \\
PU -> ATTITUDE & 0,37 & 4,38 & Sangat signifikan pada alpha 1\% dan 5\% \\
PU -> INTENTION & 0,50 & 5,11 & Sangat signifikan pada alpha 1\% dan 5\% \\
\hline
\end{tabular}

Terlihat pada Tabel 3 di atas memperlihatkan semua variabel berpengaruh positif dan sangat signifikan pada alpha 1\% dan juga 5\%, dengan Degree Of Freedom 220 sampel dikurang jumlah variabel yaitu 5 , sehingga menghasilkan $\mathrm{DF}=215$.

Evaluasi berikut adalah goodnes of fit yaitu nilai R-square seperti yang diperlihatkan pada Tabel 4 berikut. 
Tabel 4. R-square

\begin{tabular}{lr}
\hline Konstruk & R-square \\
\hline ACTUAL USE & 0,48 \\
ATTITUDE & 0,43 \\
INTENTION & 0,49 \\
PU & 0,56 \\
\hline
\end{tabular}

Berdasarkan Tabel 4 diperoleh bahwa nilai R-square konstruk PU adalah 0,56. Hal ini dapat diinterpretasikan bahwa variabilitas konstruk PU dipengaruhi oleh konstruk PEOU sebesar 56\%, sisanya 44\% dipengaruhi oleh konstruk lain di luar yang diteliti. Menurut Chin (Ghozali, 2011) nilai ini masuk dalam kategori baik. Nilai R-square konstruk attitude adalah 0,43 . Interpretasinya adalah bahwa variabilitas dari konstruk attitude yang dapat dijelaskan oleh konstruk PEOU dan PU adalah 43\%. Sisanya 57\% dijelaskan oleh variabel lain di luar yang diteliti. Menurut Chin (Ghozali, 2011) nilai ini masuk dalam kategori moderat. Konstruk intention memiliki nilai R-square 0,49. Interpretasinya adalah variabilitas dari konstruk intention yang dapat dijelaskan oleh konstruk PU dan attitude adalah $49 \%$. Sisanya $51 \%$ dijelaskan oleh variabel lain di luar yang diteliti. Menurut Chin (Ghozali, 2011) nilai ini masuk dalam kategori moderat. Konsrtuk actual use memiliki nilai R-square 0,48. Interpretasinya adalah bahwa variabilitas dari konstruk actual use yang dapat dijelaskan oleh variabel intention dan PU adalah 48\%, sisanya 52\% dijelaskan oleh variabel lain diluar yang diteliti. Menurut Chin (Ghozali, 2011) nilai ini masuk dalam kategori moderat.

Pengujian Hipotesis

Hipotesis 1 : PEOU berpengaruh positif terhadap PU. Hasil olah data diperoleh bahwa nilai $\mathrm{t}_{\text {statistik }} 18,32>\mathrm{t}_{\text {tabel }} 2,34$ pada degree of freedom $(\mathrm{DF})=(\mathrm{n}-\mathrm{k})=220-5=215$, maka disimpulkan bahwa PEOU berpengaruh terhadap PU. Dengan demikian hipotesis 1 diterima.

Hipotesis 2 : PU berpengaruh positif terhadap attitude. Hasil olah data diperoleh bahwa nilai $t_{\text {statistik }} 4,38>t_{\text {tabel }} 2,34$ pada degree of freedom $(D F)=(n-k)=220-5=215$, maka disimpulkan bahwa PU berpengaruh terhadap attitude. Dengan demikian hipotesis 2 diterima.

Hipotesis 3 : PEOU berpengaruh positif terhadap attitude. Hasil olah data diperoleh bahwa nilai $\mathrm{t}_{\text {statistik }} 3,83>\mathrm{t}_{\text {tabel }} 2,34$ pada degree of freedom $(\mathrm{DF})=(\mathrm{n}-\mathrm{k})=220-5=215$, maka disimpulkan bahwa PEOU berpengaruh terhadap attitude. Dengan demikian hipotesis 3 diterima

Hipotesis 4 : attitude berpengaruh positif terhadap intention. Hasil olah data diperoleh bahwa nilai $t_{\text {statistik }} 2,78>t_{\text {tabel }} 2,34$ pada degree of freedom $(\mathrm{DF})=(\mathrm{n}-\mathrm{k})=220-5=215$, maka disimpulkan bahwa attitude berpengaruh terhadap intention. Dengan demikian hipotesis 4 diterima.

Hipotesis 5 : intention berpengaruh positif terhadap actual use. Hasil olah data diperoleh bahwa nilai $\mathrm{t}_{\text {statistik }} 10,68>\mathrm{t}_{\text {tabel }} 2,34$ pada degree of freedom $(\mathrm{DF})=(\mathrm{n}-\mathrm{k})=220-$ $5=215$, maka disimpulkan bahwa intention berpengaruh terhadap actual use. Dengan demikian hipotesis 5 diterima.

Hipotesis 6 : PU berpengaruh positif terhadap intetntion. Hasil olah data diperoleh bahwa nilai $\mathrm{t}_{\text {statistik }} 5,11>\mathrm{t}_{\text {tabel }} 2,34$ pada degree of freedom $(\mathrm{DF})=(\mathrm{n}-\mathrm{k})=220-5=215$, maka disimpulkan bahwa PU berpengaruh terhadap intention. Dengan demikian hipotesis 6 diterima.

Hipotesis 7 : PU berpengaruh positif terhadap actual use. Hasil olah data diperoleh bahwa nilai $\mathrm{t}_{\text {statistik }} 2,57<\mathrm{t}_{\text {tabel }} 2,34$ pada degree of freedom $(\mathrm{DF})=(\mathrm{n}-\mathrm{k})=220-5=215$, 
maka disimpulkan bahwa PU berpengaruh positif dan sangat signifikan terhadap actual use. Dengan demikian hipotesis 7 diterima

\section{Pembahasan}

Persepsi Kemudahan Penggunaan (PEOU) Berpengaruh Positif Terhadap Kemudahan Penggunaan (PU) Pengujian terhadap hipotesis ini diperoleh bahwa persepsi kemudahan penggunaan (PEOU) berpengaruh positif signifikan terhadap kemudahan penggunaan (PU). Hal ini dibuktikan dengan diterimanya hipotesis ini dimana nilai $t_{\text {statistik }}>$ dari $t_{\text {tabel }}$ dengan nilai koefisien 0,75 . Pengaruh positif menunjukan pengaruh yang bersifat searah, yaitu apabila persepsi kemudahan meningkat maka persepsi kegunaan juga akan meningkat. Artinya persepsi kemudahan menggunakan SIAKAD SIAM akan meningkatkan persepsi manfaat dari SIAKAD SIAM tersebut.

Persepsi Kegunaan atau Manfaat (PU) Berpengaruh Positif Terhadap Sikap Untuk Menggunakan Teknologi (AT) Pengujian terhadap hipotesis ini diperoleh bahwa persepsi kegunaan atau manfaat (PU) berpengaruh positif signifikan terhadap sikap untuk menggunakan teknologi (AT). Hal ini dibuktikan dengan di terimanya hipotesis ini dimana nilai $t_{\text {statistik }}>$ dari $t_{\text {tabel }}$ dengan nilai koefisien 0,37 . Pengaruh positif menunjukan apabila manfaat dari menggunakan teknologi meningkat maka sikap positif untuk terus menggunakan teknologi tersebut juga akan meningkat. Artinya persepsi manfaat dari menggunakan SIAKAD SIAM akan meningkatkan sikap positif untuk menggunakan SIAKAD SIAM tersebut.

Persepsi Kemudahan Penggunaan (PEOU) Berpengaruh Positif Terhadap Sikap Untuk Menggunakan Teknologi (AT) Pengujian terhadap hipotesis ini diperoleh bahwa kemudahan penggunaan (PEOU) berpengaruh positif signifikan terhadap sikap untuk menggunakan teknologi (AT). Hal ini dibuktikan dengan di terimanya hipotesis ini dimana nilai $\mathrm{t}_{\text {statistik }}>$ dari $t_{\text {tabel }}$ dengan nilai koefisien 0,33 . Pengaruh positif menunjukan pengaruh yang bersifat searah, yaitu apabila persepsi kemudahan meningkat maka sikap positif untuk terus menggunakan SIAKAD SIAM juga akan meningkat. Artinya persepsi kemudahan menggunakan SIAKAD SIAM akan meningkatkan sikap positif untuk menggunakan SIAKAD SIAM tersebut.

Sikap Untuk Menggunakan Teknologi (AT) Berpengaruh Positif Terhadap Minat Untuk Menggunakan Teknologi (BI) Pengujian terhadap hipotesis ini diperoleh bahwa sikap untuk menggunakan teknologi (AT) berpengaruh positif signifikan terhadap minat untuk menggunakan teknologi (BI). Hal ini dibuktikan dengan di terimanya hipotesis ini dimana nilai $t_{\text {statistik }}>$ dari $t_{\text {tabel }}$ dengan nilai koefisien 0,27 . Pengaruh positif menunjukan apabila sikap positif untuk menggunakan teknologi meningkat maka minat untuk menggunakana SIAKAD SIAM juga akan meningkat. Artinya persepsi sikap atau respon positif terhadap penggunaan SIAKAD SIAM akan meningkatkan minat pengguna untuk menggunakan SIAKAD tersebut.

Minat Untuk Menggunakan Teknologi (BI) Berpengaruh Positif Terhadap Penggunaan Teknologi Sesungguhnya (ATU) Pengujian terhadap hipotesis ini diperoleh bahwa minat untuk menggunakan teknologi (BI) berpengaruh positif signifikan terhadap penggunaan teknologi sesungguhnya (ATU). Hal ini dibuktikan dengan di terimanya hipotesis ini dimana nilai $t_{\text {statistik }}>$ dari $t_{\text {tabel }}$ dengan nilai koefisien 0,56. Pengaruh positif menunjukan apabila minat untuk menggunakan teknologi meningkat maka penggunaan yang seungguhya untuk menggunakan SIAKAD SIAM sebagai manajemen akademik berbasis teknologi lembaga juga akan meningkat. Artinya minat untuk menggunakan SIAKAD SIAM akan meningkatkan penggunaan sesungguhnya dari SIAKAD tersebut. 
Kegunaan Atau Manfaat Persepsian (PU) Berpengaruh Positif Terhadap Minat Untuk Menggunakan Teknologi (BI) Pengujian terhadap hipotesis ini diperoleh bahwa kegunaan atau manfaat persepsi (PU) berpengaruh positif signifikan terhadap minat untuk menggunakan teknologi (BI). Hal ini dibuktikan dengan di terimanya hipotesis ini dimana nilai $t_{\text {statistik }}>$ dari $t_{\text {tabel }}$ dengan nilai koefisien 0,50 . Pengaruh positif menunjukan apabila manfaat dari menggunakan teknologi meningkat maka minat yang besar untuk terus menggunakan teknologi tersebut juga akan meningkat. Artinya persepsi manfaat dari menggunakan SIAKAD SIAM akan meningkatkan minat untuk menggunakan SIAKAD SIAM tersebut.

Kegunaan atau Manfaat Persepsi (PU) Berpengaruh Positif Terhadap Penggunaan Teknologi Sesungguhnya (ATU) Pengujian terhadap hipotesis ini diperoleh bahwa PU berpengaruh positif dan signifikan terhadap Actual Technology Use (ATU). Hal ini dibuktikan dengan diterimanya hipotesis ini dimana nilai $t_{\text {statistik }}>$ dari $t_{\text {tabel }}$ dengan nilai koefisien 0,18 .

\section{SIMPULAN}

Semua hipotesis yang diajukan pada penelitian ini diterima dengan Validitas di atas 0,6 dan Reliabilitas 0.7, dimana PEOU $\rightarrow$ PU nilai $t_{\text {statistik }} 18,32>t_{\text {tabel }} 2,34$ dengan koefisien 0.75, PU $\rightarrow$ Attitude nilai $\mathrm{t}_{\text {statistik }} 4,38>\mathrm{t}_{\text {tabel }}$ 2,34 dengan koefisien 0.37, PEOU $\rightarrow$ Attitude nilai $\mathrm{t}_{\text {statistik }} 3,83>\mathrm{t}_{\text {tabel }} 2,34$ dengan koefisien 0.33, Attitude $\rightarrow$ Intention nilai $\mathrm{t}_{\text {statistik }} 2,78>$ $t_{\text {tabel }}$ 2,34 dengan koefisien 0.27, Intention $\rightarrow$ Actual Use nilai $t_{\text {statistik }} 10,68>t_{\text {tabel }} 2,34$ dengan koefisien 0.56, PU $\rightarrow$ Intention nilai $\mathrm{t}_{\text {statistik }} 5,11>\mathrm{t}_{\text {tabel }} 2,34$ dengan koefisien 0.50 dan PU $\rightarrow$ Actual Usen $\mathrm{t}_{\text {statistik }} 2,57<\mathrm{t}_{\text {tabel }} 2,34$ dengan koefisien 0.18. Evaluasi menggunakan Technology Acceptance Model (TAM) berdasarkan hasil pengukuran menyatakan bahwa pengguna berpresepsi mudah dan bermanfaat dalam menggunakan teknologi tersebut dan tidak ditemukan faktor-faktor yang menghambat pemanfaatan SIAKAD SIAM sebagai sebagai salah satu manajemen akademik berbasis teknologi informasi STKIP Hamzanwadi Selong. Technology Acceptance Model (TAM) juga menyimpulkan bahwa semua pengguna benar-benar memanfaatkan seluruh fitur teknologi pada aplikasi SIAKAD SIAM dengan diterimanya Variabel Penggunaan Sesungguhnya (ATU) pada pemanfaatan sebuah teknologi.

\section{REFRENSI}

Ghozali (2011). Structural Equation Modeling Metode Alternatif dengan Partial Least Square, Penerbit Badan Penerbit Universitas Diponegoro, Semarang.

Jogianto (2008). Sistem Informasi Keprilakuan', Penerbit Andi, Yogyakarta.

Kadir, A. (2003). Pengenalan Sistem Informasi. Yogyakarta: Penerbit Andi.

Notohadiprawiro, T. (2006). Sistem Informasi Pengertian dan Kepentingannya. Seminar Nasional Plantagarna. hal. 1-7. Yogyakarta: Fakultas Pertanian UGM.

Rencana Strategis STKIP Hamzanwadi Selong 2011-2015.

Singarimbun, Masri, Efendi, \& Sofian, (2003), Metode Penelitian Survai. Pusat penelitian dan Studi kependudukan, Universitas Gadjah Mada Yogyakarta.

Wijaya, T, (2009), Analisis Structural Modeling, Penerbit Andi, Yogyakarta. 